EFFECTIVENESS BULLETIN

\title{
Inhaler devices for the treatment of asthma and chronic obstructive airways disease (COPD)
}

\author{
J Wright, D Brocklebank, F Ram
}

Qual Saf Health Care 2002;11:376-382

The research evidence on the effectiveness of inhaler devices for the treatment of asthma and chronic obstructive pulmonary disease published in a recent issue of Effective Health Care is reviewed.

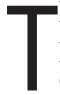
his article summarises the research evidence presented in a recent issue of Effective Health Care on inhaler devices for the treatment of asthma and chronic obstructive airways disease (COPD).

\section{BACKGROUND}

Inhaled therapy delivering bronchodilator and corticosteroid drugs in various doses has become accepted as the mainstay of treatment for patients with asthma and chronic COPD. ${ }^{2}{ }^{3}$ It allows low doses of medication to be delivered directly to the site of action in the airways, significantly reducing systemic side effects compared with oral therapy. The aim of inhaled therapy is to reverse and prevent airway inflammation and constriction and minimise symptoms. The two main categories of inhaled drugs are bronchodilators and corticosteroids. Bronchodilators (short and long acting $\beta_{2}$ agonists and antimuscarinic drugs) relieve symptoms of bronchoconstriction. Corticosteroids reduce airways inflammation to prevent symptoms of asthma.

A number of different inhalation devices are available. The pressurised metered dose inhaler (pMDI) is the most commonly used and cheapest device, which may also be used in conjunction with a spacer device. Newer chlorofluorocarbon (CFC)-free inhaler devices using hydrofluoroalkanes (HFAs) have also been developed. The drug is dissolved or suspended in the propellant under pressure. When activated, a valve system releases a metered volume of drug and propellant. Spacer chambers can be attached to pMDIs to make them easier to use.

Other devices include breath actuated pMDIs such as Autohaler and Easibreathe. They enable the patient to prime the inhaler which is then only actuated when the patient takes a breath, avoiding the need to coordinate actuation with breathing. Dry powder inhalers (DPI) such as Turbohaler, Diskhaler, Accuhaler and Clickhaler are also activated by inspiration by the patient. The powdered drug is dispersed into particles by the inspiration.

Nebulisers use oxygen, compressed air, or ultrasonic power to break up solutions or suspensions of medication into droplets for inhalation. The aerosol is administered by a mask or mouthpiece. However, nebulisers are more expensive than pMDIs, require a power source, and need regular maintenance.

There is a confusing array of inhaler devices available for the treatment of asthma and COPD. The competing claims of pharmaceutical companies make it difficult for prescribers to choose the best device for different patients. This article summarises the current research evidence on the clinical and cost effectiveness of these pMDIs (with or without a spacer device) compared with other hand held inhaler devices. It updates the evidence from a number of systematic reviews carried out by the Cochrane Airways Group and funded by the NHS Health Technology Assessment Programme. ${ }^{4}$ The original reviews were used as supporting evidence for two technology appraisal guidance reports for the National Institute for Clinical Excellence ${ }^{56}$ and for forthcoming guidance from the British Thoracic Society. Details of the additional randomised controlled trials (RCTs) included in the update can be found in table 1.

\section{RANGE AND COSTS OF DRUGS AND DEVICES}

The annual cost to the NHS for asthma drugs is over $£ 500$ million. $^{7}$ A large number of inhaler devices and drug/device combinations are commercially available. There are considerable differences in the costs of the same drug using different inhaler devices and of the drugs used in specific devices. ${ }^{8}$ The use of a specific inhaler device may limit prescribing choice to more expensive proprietary drugs. In addition, some inhaler and drug combinations are limited by commercial availability.

Clinical guidelines on the use of inhalers for asthma and COPD have been published from a number of sources..$^{2}{ }^{3}{ }^{10}$ However, the recommendations for inhaler devices from these guidelines are either absent, vague, or inconsistent. Evidence based guidelines are currently being developed by the British Thoracic Society.

\section{EFFECTIVENESS OF HAND HELD INHALER DEVICES FOR ASTHMA}

Delivery of corticosteroids in stable asthma

Three studies in children comparing different devices failed to show significant differences in pulmonary function between the devices. ${ }^{11-13}$

Three further studies in children were identified ${ }^{14-16}$ but the heterogeneity of the original studies precluded any pooling of results. This remains the case with the addition of the new studies. Farmer et al ${ }^{14}$ studied 229 children with asthma aged 7-12 years and compared a CFC and 


\begin{tabular}{|c|c|c|c|c|}
\hline Study & Methodology & Details & Results & Comments \\
\hline Crompton $^{40}$ & $\begin{array}{l}\text { Design: parallel open } \\
\text { Device: pMDI+Nebuhaler } v \text { Turbuhaler } \\
\text { Drug: budesonide } \\
\text { Dose: "usual dose" } \\
\text { Duration: } 12 \text { weeks }\end{array}$ & $\begin{array}{l}\text { Participants: } 72 \text { asthmatics, mean age } \\
\text { 47. Mean } \mathrm{FEV}, \% \text { predicted, } 68 \% . \\
\text { Cochrane Quality: B }\end{array}$ & $\begin{array}{l}\text { 4-point dysphonia score reported, } \mathrm{FEV}_{\text {, }} \text { and FVC } \\
\text { measured but only reported "no significant } \\
\text { change in either group". Other non-clinical } \\
\text { outcomes measured (laryngoscopy, voice } \\
\text { analysis) }\end{array}$ & $\begin{array}{l}72 \text { randomised, } 64 \text { completed and } 51 \\
\text { "considered evaluable for per protocol } \\
\text { analysis". Specifically designed to identify } \\
\text { voice changes rather than asthma control. }\end{array}$ \\
\hline Farmer $^{14}$ & $\begin{array}{l}\text { Design: Parallel, double blind } \\
\text { Device: HFA } \vee \text { CFC Easibreathe breath actuated pMDIs } \\
\text { Drug: Beclomethasone } \\
\text { Dose: } 200 \text { g daily } \\
\text { Duration: } 12 \text { weeks }\end{array}$ & $\begin{array}{l}\text { Participants: } 229 \text { asthmatics aged 7-12, } \\
199 \text { supplied evaluable data. } \\
\text { Cochrane Quality: B }\end{array}$ & $\begin{array}{l}\text { No significant differences in diary card PEFR, } \\
\mathrm{FEV}_{1} \text {, symptom scores, adverse events, serum } \\
\text { cortisol from } 19 \% \text { of the population }\end{array}$ & $\begin{array}{l}\text { Authors' power calculation shows this to be } \\
\text { underpowered to demonstrate equivalence }\end{array}$ \\
\hline Goldin ${ }^{41}$ & $\begin{array}{l}\text { Design: Parallel, double blind, double dummy } \\
\text { Device: CFC } v \text { HFA pMDI } \\
\text { Drug: Beclomethasone } \\
\text { Dose: } 200 \mu \text { g daily } \\
\text { Duration: } 12 \text { weeks }\end{array}$ & $\begin{array}{l}\text { Participants: } 34 \text { asthmatics aged 19-56 } \\
\text { years. Mean FEV } 80 \% \text { predicted } \\
\text { Cochrane Quality: B }\end{array}$ & $\begin{array}{l}\text { Diary card PEFR, symptom scores and } \\
\text { beta-agonist use, } \mathrm{FEV}_{1} \text {, methacholine challenge }\end{array}$ & $\begin{array}{l}\text { Primary outcome was air trapping as measured } \\
\text { by CT imaging. This is non-clinical and was not } \\
\text { included in this analysis }\end{array}$ \\
\hline $\begin{array}{l}\text { Juniper } \\
\text { Gross }^{42} \text { ) }\end{array}$ & $\begin{array}{l}\text { Design: Parallel, single blind } \\
\text { Device: HFA } \vee \text { CFC pMDIs } \\
\text { Drug: Beclomethasone } \\
\text { Dose: } 400 \mu \mathrm{g} v 800 \mu \mathrm{g} \text { daily } \\
\text { Duration: } 12 \text { weeks }\end{array}$ & $\begin{array}{l}\text { Participants: } 347 \text { moderate asthmatics } \\
\text { (162 M, 185F), mean age } 33 \text { (3rd arm of } \\
117 \text { patients received HFA placebo) } \\
\text { Cochrane Quality: B }\end{array}$ & $\begin{array}{l}\text { Asthma quality of life questionaire, daytime } \\
\text { symptoms and sleep disturbance scores }\end{array}$ & Supplementary report of results to Gross. ${ }^{77}$ \\
\hline Pearlman ${ }^{15}$ & $\begin{array}{l}\text { Design: Parallel, double blind } \\
\text { Device: HFA } \vee \text { CFC pMDls } \\
\text { Drug: Triamcinolone } \\
\text { Dose: } 150,300 \text { and } 600 \mathrm{mg} \text { daily, } 6 \text { arms } \\
\text { Duration: } 12 \text { weeks }\end{array}$ & $\begin{array}{l}\text { Participants: } 473 \text { children aged 6-13 } \\
\text { years enrolled, } 374 \text { completed } \\
\text { Cochrane Quality: B }\end{array}$ & $\begin{array}{l}\% \text { change } \mathrm{FEV}_{1} \text {, change in } \beta \text { agonist use, } \\
\mathrm{FEF}_{25-75 \%} \text { PEFR, night time wakening, symptom } \\
\text { scores, adverse events }^{\text {a d a }}\end{array}$ & \\
\hline Rufin $^{16}$ & $\begin{array}{l}\text { Design: Parallel, open trial } \\
\text { Device: } \mathrm{pMDI+spacer} \vee \text { Autohaler } \\
\text { Drug: Beclomethasone } \\
\text { Dose: } 1000 \mu \mathrm{g} \text { daily } \\
\text { Duration: } 8 \text { weeks }\end{array}$ & $\begin{array}{l}\text { Participants: } 127 \text { asthmatic children 5-15 } \\
\text { years old, mean age } 11 \\
\text { Cochrane Quality: B }\end{array}$ & $\mathrm{FEV}_{1}$, mid-flows, patient acceptability & \\
\hline Stradling ${ }^{39}$ & $\begin{array}{l}\text { Design: Parallel, double blind, double dummy } \\
\text { Device: pMDI+spacer } v \text { Clickhaler } \\
\text { Drug: Beclomethasone } \\
\text { Dose: "usual" dose } \\
\text { Duration: } 12 \text { weeks }\end{array}$ & $\begin{array}{l}\text { Participants: } 240 \text { asthmatics entered run } \\
\text { in, } 204 \text { randomised. Mean age } 50 \text { years } \\
\text { Cochrane Quality: B }\end{array}$ & $\begin{array}{l}\text { PEFR (am, pm), daytime, night time symptom } \\
\text { scores (FEV } 1 \text {, FVC only reported } \\
\text { "non-significant"), exacerbations, adverse } \\
\text { events, serum cortisol }\end{array}$ & Unclear if ITT analysis used \\
\hline Maladano-Alanis ${ }^{72}$ & $\begin{array}{l}\text { Design: } 3 \text { way parallel, open study } \\
\text { Device: } \mathrm{pMDI}+\text { Pulmona spacer } v \mathrm{pMDI}+\text { Ellipse } v \text { Hudson nebuliser } \\
\text { Drug: Salbutamol } \\
\text { Dose: } 200 \vee 200 \mu \mathrm{gg} \vee 150 \mu \mathrm{gg} / \mathrm{kg} \\
\text { Duration: } 6 \text { hours }\end{array}$ & $\begin{array}{l}\text { Participants: } 63 \text { asthmatic children aged } \\
6-15 \text { years. } \\
\text { Cochrane Quality: B }\end{array}$ & $\begin{array}{l}\mathrm{FEV}, \text { at } 5,20,60 \text { minutes and } 2,3,4,5,6 \\
\text { hours. Reported equal at } 1 \text { hour }(24 \% \text { increased) } \\
\text { but at } 6 \text { hours the nebuliser had decreased least } \\
(15.5 \vee 14.7 \vee 5.5 \%)\end{array}$ & \\
\hline Salzman ${ }^{71}$ & $\begin{array}{l}\text { Design: Crossover, open trial } \\
\text { Device: pMDI+spacer } v \text { Hudson Updraft II nebuliser at } 6 \mathrm{I} / \mathrm{min} \\
\text { Drug: Metaproterenol } \\
\text { Dose: } 1.3 \mathrm{v} 15 \mathrm{mg} \\
\text { Duration: } 2 \times 1 \text { day }\end{array}$ & $\begin{array}{l}\text { Participants: } 15 \text { adult severe asthmatics, } \\
18-47 \text { years } \\
\text { Cochrane Quality: B }\end{array}$ & $\begin{array}{l}\text { Mean \% increases in FEV } 1, \text { FVC, PEFR, MMFR, } \\
\text { FEF }_{25-75 \%}\end{array}$ & \\
\hline
\end{tabular}

Table 1 Additional randomised clinical trials included in the Effective Health Care update 


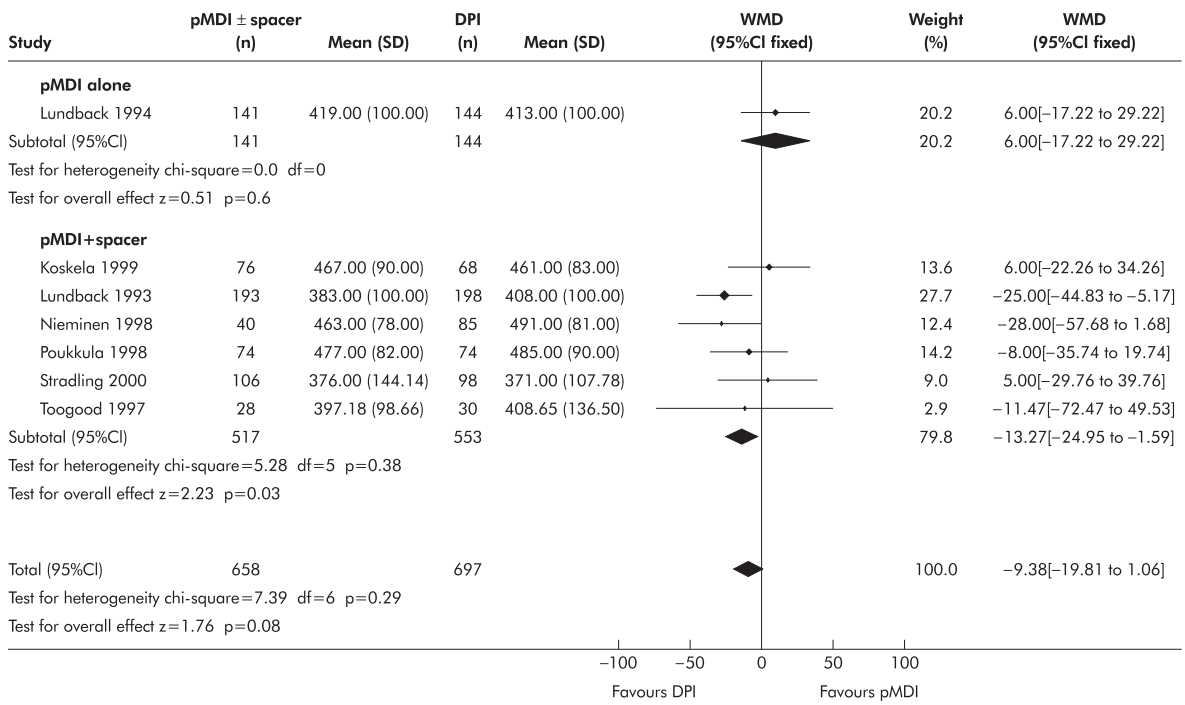

Figure 1 Absolute difference in FEV, between $\mathrm{PMDI}$ and dry powder inhaler (DPI) for the delivery of corticosteroids in stable asthma (Z statistic (2.23) indicates the level of significance for the overall result).

HFA Easibreathe (breath actuated inhaler) delivering beclomethasone dipropionate. No differences were found in diary card peak flow expiratory rate (PEFR), forced expiratory volume in 1 second $\left(\mathrm{FEV}_{1}\right)$, symptoms scores, adverse events, and serum cortisol levels from 19\% of the population. Pearlman et al $^{15}$ studied 473 children aged 6-13 years with asthma. Triamcinolone (not licensed in the UK) was given at 150, 300 and $600 \mu \mathrm{g}$ daily by CFC and HFA pMDI devices. No clinically significant differences were found in $\beta$ agonist use, forced expiratory mid flow $\left(\mathrm{FEF}_{25-75 \%}\right)$, PEFR, night-time wakening, symptom scores, and adverse events. Rufin $e t$ a $l^{16}$ studied 127 5-15 year old children with asthma. Beclomethasone dipropionate was delivered $1000 \mu \mathrm{g}$ daily via a pMDI plus large volume spacer versus an Autohaler (breath actuated inhaler). No clinically significant differences were found in FEV , and expiratory mid flow rates.

Twenty one studies in adults found no significant difference in measures of pulmonary function, symptom scores, exacerbation rates, and adverse effects such as hoarse voice, oral thrush, and effects on the hypothalamic-adrenal axis (serum cortisol) between a pMDI and a dry powder inhaler, hydrofluoroalkane pMDI, or breath actuated pMDI for the delivery of corticosteroids. ${ }^{17-38}$ Figure 1 shows the absolute difference in $\mathrm{FEV}_{1}$ between $\mathrm{pMDI}$ and dry powder inhaler for the delivery of corticosteroids in stable asthma. ${ }^{22} 2233353639$ Statistically significant differences were found for three outcomes for dry powder inhalers, but these were either within clinically equivalent limits or the differences were not apparent once baseline characteristics were taken into account.

Four further studies have since been identified. ${ }^{39-42}$ Juniper and Buist ${ }^{42}$ reported asthma related quality of life questionnaire scores from a previous study. ${ }^{30}$ No significant differences were found between inhaler devices. In the study by Crompton et $a l^{40} 51$ patients with asthma were studied to evaluate the effect on voice changes rather than asthma control between pMDI+Nebuhaler vs Turbohaler for the delivery of budesonide. Clinical outcomes were also measured but no significant differences were found between the devices. Goldin et $a l^{41}$ studied 34 asthmatics taking beclomethasone $200 \mu \mathrm{g}$ daily via a CFC or HFA pMDI. The primary outcome of the study was air trapping as measured by CT imaging. Other clinical outcomes were measured and no significant differences were found. Stradling et a ${ }^{39}$ included 204 asthmatics taking beclomethasone at their "usual" dose via pMDI+ spacer or Clickhaler. No significant differences were found.
The addition of data from these four studies to the original meta-analysis made no significant change to the results. For the delivery of inhaled steroids in stable asthma in children over 5 years and adults, pMDI (with or without spacer) is as effective as other hand held inhaler devices. There is no evidence to demonstrate differences in drug delivery between non-CFC pMDI and CFC pMDI at equivalent doses.

\section{Delivery of short acting $\beta_{2}$ agonist bronchodilators in chronic asthma}

A Cochrane review and meta-analysis of 84 RCTs found no differences between pMDI and 10 other hand held inhaler devices for lung function, blood pressure, symptoms, bronchial hyperreactivity, systemic bioavailability, inhaled steroid requirement, serum potassium, and use of additional relief bronchodilators. ${ }^{43}$ In addition, no evidence was found to support claims that higher dosing schedules (2:1 or greater) had any clinical advantage over $1: 1$ dosing.

Regular use of HFA-pMDI containing salbutamol reduced the requirement for short courses of oral corticosteroids. These data were provided by three trials with a total of 519 patients (fig 2) ${ }^{44}{ }^{45}$ However, the total number of exacerbations in these three trials was unchanged. The effect of HFA-pMDI on requirement for oral corticosteroid courses to treat acute exacerbations therefore needs to be confirmed.

Three trials in adults found a lower pulse rate in patients using pMDI than those using Turbohaler, suggesting greater

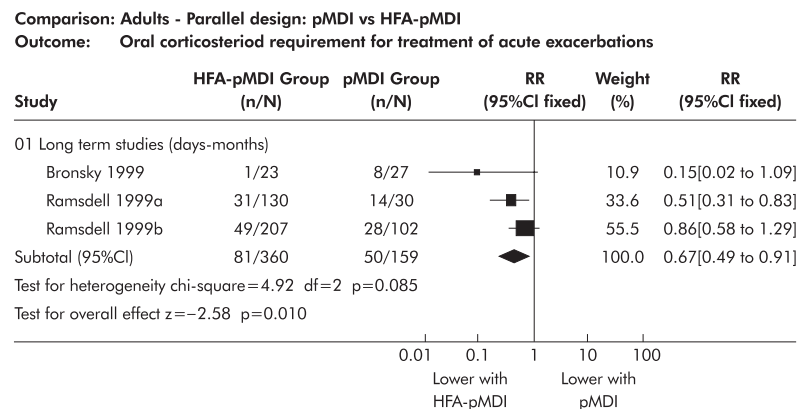

Figure 2 Short course oral corticosteroid requirement for acute exacerbations in adult patients with asthma. Data from three long term parallel design trials (represented as relative risk calculated using fixed effect model with $95 \%$ confidence intervals; Z statistic (2.58) indicates the level of significance for the overall result). 


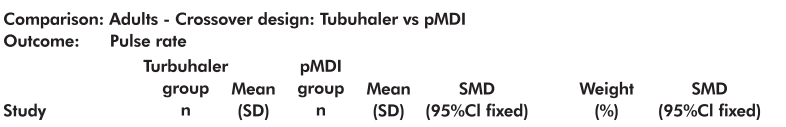

01 Cumulative dosing studies

Bondesson $1998 \quad 1295.00(7.75) 1289.00(7.50) \quad \longrightarrow 22.3 \quad 0.76[-0.07$ to 1.59$]$

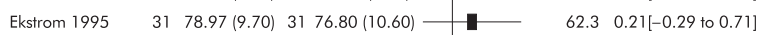

Johnsen $1988 \quad 9 \quad 21.00(8.50) 910.50(9.90) \longrightarrow 15.3 \quad 1.08[0.08$ to 2.09$)$

$\begin{array}{lllll}\text { Subtotal }(95 \% \mathrm{Cl}) \quad 52 & 52 & 100.0 & 0.47[0.07 \text { to } & 0.86]\end{array}$

Test for heterogeneity chi-square $=2.92 \mathrm{df}=2 \mathrm{p}=0.23$

Test for overall effect $z=2.32 \quad p=0.02$

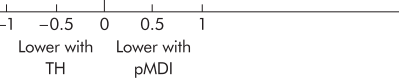

Figure 3 Mean (95\% confidence interval) pulse rate (bpm) outcome from three cumulative dosing trials ( $Z$ statistic $(2.71)$ indicates the level of significance for the overall result).

systemic absorption with the Turbohaler device compared with the pMDI (fig 3). ${ }^{46-48}$

Three studies found that adult patients preferred pMDI to the less commonly used Rotahaler device (fig 4). ${ }^{49-51}$ However, this result should be interpreted with caution because of the potential for bias due to lack of blinding.

For the delivery of inhaled short acting $\beta_{2}$ agonists in chronic asthma, pMDI (with or without spacer) is as effective as any other hand held inhaler device.

\section{CLINICAL EFFECTIVENESS OF HAND HELD INHALER DEVICES FOR COPD}

A Cochrane systematic review compared pMDI with other devices. $^{52}$ No significant difference in clinical outcomes was found between dry powder devices and pMDI for delivery of $\beta_{2}$ agonists. A soft mist device for ipratropium (Respimat) was more effective than a pMDI in improving lung function but the data came from one small study. The dearth of published studies highlights a major gap in the research evidence for this important area.

\section{EFFECTIVENESS OF NEBULISERS Chronic asthma}

Three studies in children totalling 51 participants compared different hand held inhaler devices with a nebuliser and found no evidence of clinical superiority of nebulisers over inhaler devices. ${ }^{53-55}$ Twenty three studies in adults showed clinical equivalence for inhaler devices and nebulisers for the main

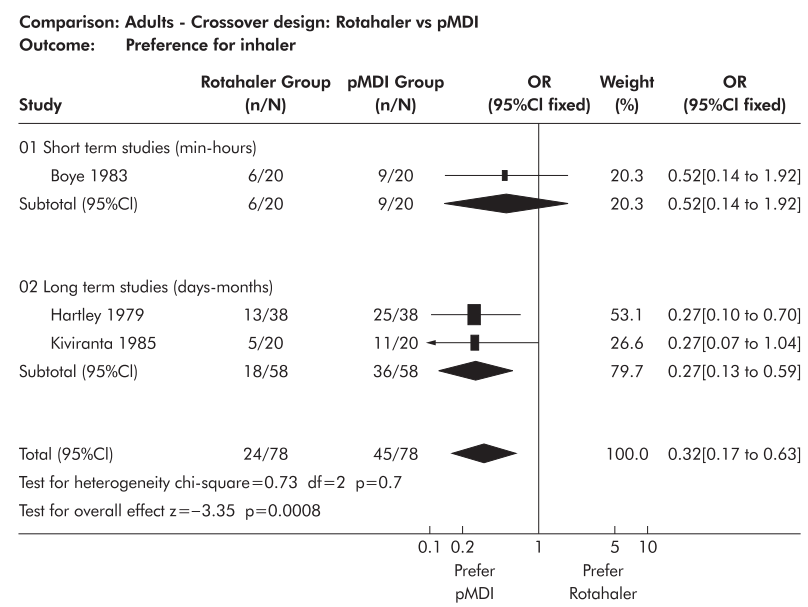

Figure 4 Inhaler device preference in adult patients with asthma. Data from one short term and two long term crossover design trials (represented as odds ratio calculated using fixed effect model with $95 \%$ confidence intervals; Z statistic (3.35) indicates the level of significance of the overall effect size). pulmonary outcomes ( $\mathrm{FEV}_{1}$ and PEFR) and no evidence of significant difference in other outcomes. ${ }^{56-69}$

Figure 5 shows the standardised mean difference of FEV between nebulisers and hand held inhaler devices for the delivery of $\beta$ agonists in stable asthma. ${ }^{54-60} 62$ 63 65-67 69-71

Updated searching identified two further studies. ${ }^{71} 72$ Maldonado-Alanis et al ${ }^{72}$ evaluated the bronchodilator response of 63 children over 6 hours in a three way parallel study. The results were published as an abstract only and detailed statistical results were not shown. The initial bronchodilator response for salbutamol was similar between pMDI+Pulmona spacer, pMDI+Ellipse spacer $(200 \mu \mathrm{g}$ from each) and a nebuliser (at a dose of $150 \mu \mathrm{g} / \mathrm{kg}$ ).

Salzman and Pyszczynski ${ }^{71}$ included 15 patients with severe stable asthma in a 2-day open crossover trial of metaproterenol $1.3 \mathrm{mg}$ via pMDI+Aerochamber spacer device versus $15 \mathrm{mg}$ via a nebuliser. No statistically significant differences in expiratory airflow were found between the delivery methods.

\section{Acute asthma}

A Cochrane systematic review of 16 trials comparing pMDI + spacer with nebulisers for the delivery of $\beta_{2}$ agonists for mild and moderate exacerbations of asthma found that clinical outcomes from pMDIs were at least equivalent to nebulisers and may have some advantages for children. ${ }^{73}$ Children over 5 years and adults with mild and moderate exacerbations should be treated with pMDI+spacer with bronchodilator dose titration according to clinical response.

\section{COPD}

Thirteen trials have compared bronchodilator drugs delivered by inhaler devices compared with nebulisers for the treatment of patients with acute and stable COPD. ${ }^{66}{ }^{74-85}$ There was considerable variation in settings and the drugs and delivery devices used, making comparisons difficult. However, a metaanalysis supported the findings of individual studies that there is no evidence to suggest clinical benefit of nebulisers over a standard pMDI with spacer, although a higher dose may be required.

\section{INHALER TECHNIQUE}

The effectiveness of inhaler devices depends on more than just the devices themselves. Patient technique is crucial to effective drug delivery and will depend on factors such as patient experience, education, physical ability, and effective teaching of technique.

A systematic review of RCTs and observational studies supports the anecdotal impression and prejudice that pMDI devices are not used as effectively as dry powder inhalers. ${ }^{4}$ The percentage of patients with correct technique (assessed by a scoring system of correct steps) was 43\% compared with 55\% for pMDI with spacer and 59\% for dry powder inhalers. However, teaching had a positive effect and eliminates significant differences between devices by increasing the percentage of patients with correct technique to $63 \%$ for pMDI and $65 \%$ for dry powder inhalers.

Differences in effective patient technique therefore appear to owe more to the lack of teaching than to inherent differences in the devices themselves. All patients should receive appropriate instruction and guidance on effective technique when prescribed inhaler devices, and this should be regularly reinforced.

\section{IMPLICATIONS}

This article is based on systematic reviews that report average clinical effects from the trial results across drugs, doses, and devices. It may well be that, just as individual patients receive a dose tailored to their needs, they also require devices tailored to their individual needs. However, on the basis of the available evidence, there is no reason to expect alternative inhaler 


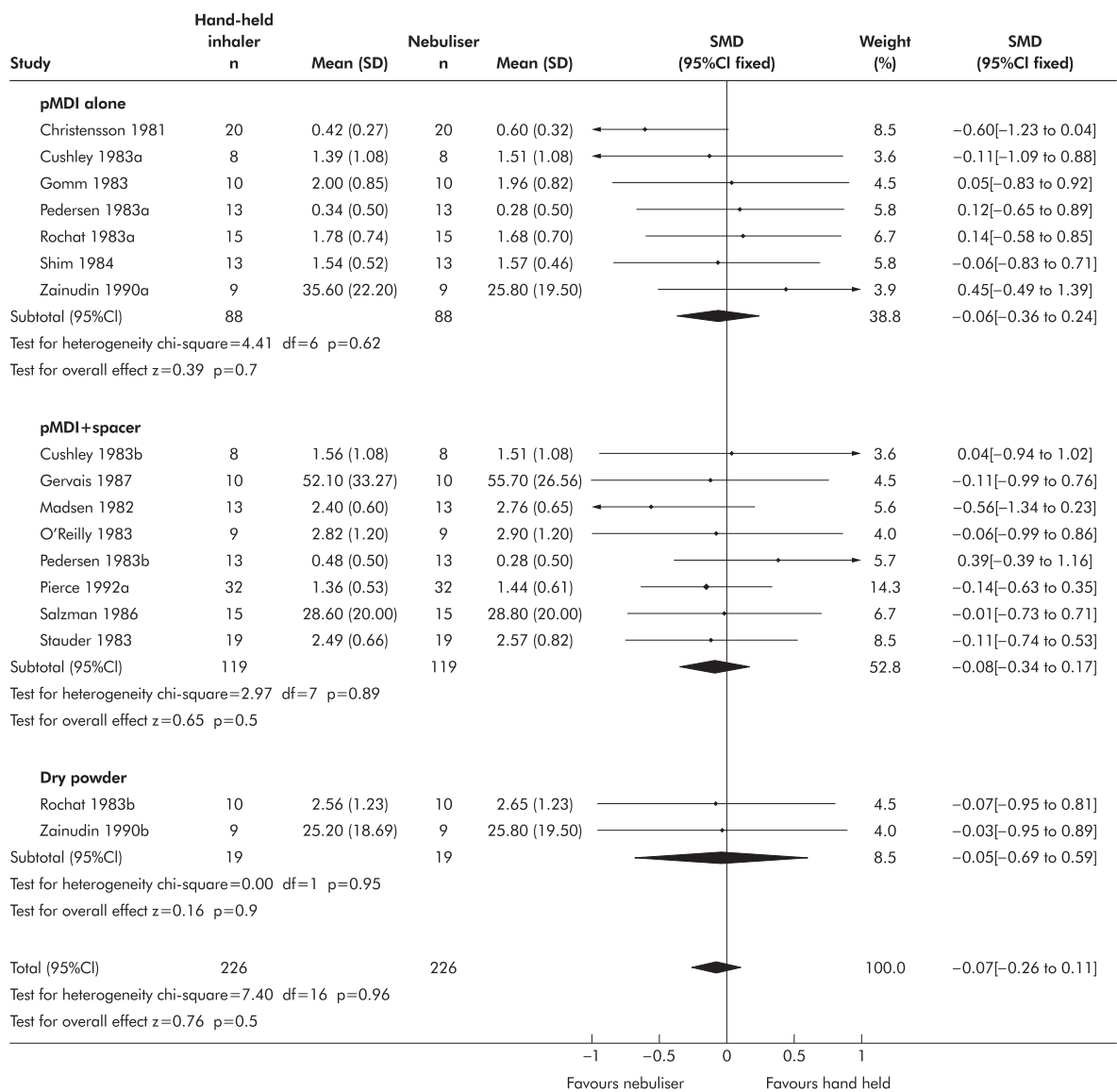

Figure 5 Standardised mean difference (SMD) of FEV, between nebulisers and hand held inhaler devices for the delivery of $\beta$ agonists in stable asthma.

devices to be clinically more effective than pMDIs (with or without a spacer) for delivery of short acting $\beta_{2}$ bronchodilators or corticosteroids. pMDIs (with or without a spacer), or the cheapest inhaler device the patient can adequately use, should therefore be prescribed as first line in all adults and children with stable asthma or COPD requiring inhaled medication. More expensive devices such as dry powder inhalers should be reserved for patients who do not have the technique or coordination to use pMDIs effectively after appropriate teaching.

Further high quality RCTs are required to be able to make valid recommendations on the use of the various inhaler devices available for the treatment of asthma or COPD. This is of particular importance because of the phasing out of CFC propellants in pMDIs. Studies should be of sufficient duration to be clinically relevant and with medication doses that are clinically appropriate. They should be undertaken in real life community setting to ensure generalisability of results.

At present the introduction of a new device for the delivery of inhaled drugs needs far less rigorous testing than for a new drug by an old device. The licensing requirement is to demonstrate equivalence to an existing device. Equivalence is not the same as failing to detect a difference, and the design and powering of trials is specific and not without controversy. It may be that stricter controls are needed before approval

Given the chronic nature of asthma and COPD and their significant effects on morbidity, future trials should address the paucity of patient centred outcomes such as quality of life, adherence, nocturnal awakening, and days off work or school. In addition, adverse effects and systemic effects should be recorded more completely. If devices share equivalent effectiveness, then secondary factors such as adverse effects become much more significant.
The teaching of inhaler technique is another important area for future research. Studies should explore the effectiveness and frequency of patient education and consider interventions to improve it. In addition, studies of teaching of inhaler technique should measure health related outcomes as the relationship between inhaler technique and clinical outcome has not been established.

\section{Authors' affiliations}

J Wright, D Brocklebank, F Ram, Department of Epidemiology and Public Health, Bradford Hospitals NHS Trust, Royal Infirmary, Bradford BD9 6RI, UK

\section{REFERENCES}

1 NHS Centre for Reviews and Dissemination. Inhaler devices for the treatment of asthma and chronic obstructive airways disease (COPD). Effective Health Care 2002;7.

2 COPD Guidelines Group of the Standards of Care Committee of the BTS. BTS guidelines for the management of chronic obstructive pulmonary disease. Thorax 1997;52(Suppl 5):S1-28.

3 British Thoracic Society, National Asthma Campaign, Royal College of Physicians. The British guidelines on asthma management: 1995 review and position statement. Thorax 1997;52(Suppl 1):S1-21.

4 Brocklebank D, Ram F, Wright J, et al. Comparison of effectiveness of inhaler devices in asthma and chronic obstructive airways disease: a review of the literature. Health Technol Assess 2001;5(2b).

5 National Institute for Clinical Excellence. Guidance on the use of inhaler systems (devices) in children under the age of 5 years with chronic asthma. 10. London: National Institute for Clinical Excellence, 2000.

6 National Institute for Clinical Excellence. Inhaler devices for routine treatment of chronic asthma in older children (aged 5-15 years). 38 London: National Institute for Clinical Excellence, 2002.

7 Neville RG, Pearson MG, Richards NPJ, et al. A cost analysis on the pattern of asthma prescribing in the UK. Eur Respir J 1999;14:605-9. 
8 British Medical Association, Royal Pharmaceutical Society of Great Britain. British National Formulary. London: British Medical Association, Royal Pharmaceutical Society of Great Britain, 2002

9 National Heart, Lung and Blood Institute. Guidelines for inhaler devices. www.nhlbl.nih gov guidelines/asthma/asthgdln.htm

10 Anon. Inhaler devices for asthma. Drug Ther Bull 2000;38:9-13.

11 Adler LM, Clarke IC, and members of the PANDA 3 clinical study group. Efficacy and safety of beclomethasone dipropionte (BDP) delivered via a novel dry powder inhaler (Clickhaler) in paediatric patients with asthma. Thorax 1997;52:A57.

12 Agertoft L, Pederson S. Importance of the inhalation device on the effect of budesonide. Arch Dis Child 1993;69:130-3

13 Edmunds AT, McKenzie S, Tooley M, et al. A clinical comparison of beclomethasone dipropionate delivered by pressurised aerosol and as a powder from a Rotahaler. Arch Dis Child 1979;54:233-5.

14 Farmer IS, Middle M, Savic J, et al. Therapeutic equivalence of inhaled beclomethasone dipropionate with CFC and non-CFC (HFA 134a) propellants: both delivered via the Easibreathe ${ }^{(T M)}$ inhaler for the treatment of paediatric asthma. Respir Med 2000;94:57-63.

15 Pearlman DS, Kane RE, Banjeri D. Comparative dose-ranging study of triamcinolone acetonide inhalation aerosol using propellants hydrofluoroalkane 134a or P-12 in children with chronic asthma. Curr Ther Res Clin Exp 1999;60:595-606.

16 Rufin P, Iniguez JL, Calvayrac P, et al. Comparison of the efficacy, tolerance and acceptability of beclomethasone dipropionate delivered by Prolair Autohaler versus a standard aerosol doser linked to a space device in children. J Pediatr Pueric 2000;13:105-10.

17 Drepaul BA, Payler DK, Qualtrough JE, et al. Becotide or Becodisks? A controlled study in general practice. Clin Trials J 1989;26:335-44.

18 Milanowski J, Qualtrough J, Perrin VL. Inhaled beclomethasone (BDP with non-CFC propellant (HFA 134a) is equivalent to BDP-CFC for the treatment of asthma. Respir Med 1999;93:245-51.

19 Vidgren $M$, Arppe J, Vidgren $P$, et al. Pulmonary deposition and clinical response of $99 \mathrm{mTc}$-labelled salbutamol delivered from a novel multiple dose powder inhaler. Pharmacol Res 1994;11:1320-4.

20 Busse W, Brazinsky S, Jacobson K, et al. Efficacy response of inhaled beclomethasone dipropionate in asthma is proportional to dose and is improved by formulation with a new propellant. J Allergy Clin Immunol 1999:104:1215-22.

21 Lundback B, Alexander M, Day J, et al. Evaluation of fluticasone propionate $(500 \mu \mathrm{g} /$ day) administered either as a dry powder via a Diskhaler or pressurized inhaler and compared with beclomethasone diprionate (1000 $\mu \mathrm{g} /$ day) administered by pressurized inhaler. Respir Med 1993;87:609-20.

22 Nieminen MM, Vidgren P, Kokkarinen J, et al. A new beclomethasone dipropionate multidose inhaler in the treatment of bronchial asthma. Respiration 1998;65:275-81.

23 Chatteriee SS, Butler AG. Beclomethasone in asthma: a comparison of two methods of administration. Br J Dis Chest 1980;74:175-9.

24 Lal S, Malhotra SM, Gribben MD, et al. Beclomethasone dipropionate aerosol compared with dry powder in the treatment of asthma. Clin Allergy 1980;10:259-62.

25 Engel T, Heinig $H$, Malling $H J$, et al. Clinical comparison of inhaled budesonide delivered either via pressurised metered dose inhaler or Turbuhaler. Allergy 1989;44:220-5.

26 Nieminen $M M$, Lahdensuo A. Inhalation treatment with budesonide in asthma. A comparison of Turbuhaler and metered dose inhalation with Nebuhaler. Acta Ther 1995;21:179-92.

27 Dahl R, Ringdal N, Ward SM, et al. Equivalence of asthma control with new CFC-free formulation HFA-134a beclomethasone dipropionate and CFC-beclomethasone dipropionate. Br J Clin Pract 1997;51:11-5.

28 Demedts $M$, Cohen R, Hawkinson R. Switch to non-CFC inhaled corticosteroids: a comparative efficacy study of HFA-BDP and CFC-BDP metered-dose inhalers. Int J Clin Pract 1999:53:331-8.

29 Davies RJ, Stampone P, O'Connor BJ. Hydrofluoroalkane-134a beclomethasone dipropionate extrafine aerosol provides equivalent asthma control to chlorofluorocarbon beclomethasone dipropionate at approximately half the total daily dose. Respir Med 1998;92(Suppl A):23-31.

30 Gross G, Thompson PJ, Chervinsky P, et al. Hydrofluoroalkane-134a beclomethasone dipropionate, $400 \mu \mathrm{g}$ is as effective as chlorofluorocarbon beclomethasone dipropionate, $800 \mu \mathrm{g}$ for the treatment of moderate asthma. Chest 1999;115:343-51.

31 Carmichael J, Duncan D, Crompton GK. Beclomethasone dipropionate dry-powder inhalation compared with conventional aerosol in chronic asthma. BM 1978:2:657-8.

32 Koskela T, Hedman J, Ekroos $\mathrm{H}$, et al. Equivalence of two steroid-containing inhalers: Easyhaler multidose powder inhale compared with conventional aerosol with large volume spacer Respiration 2000;67:194-202.

33 Lundback B, Dahl R, De Jonghe $M$, et al. A comparison of fluticasone propionate when delivered by either the metered-dose inhaler or the Diskhaler in the treatment of mild-to-moderate asthma. Eur J Clin Res 1994; 5: 11-9

34 Morrison Smith J, Gwynn CM. A clinical comparison of aerosol and powder administration of beclomethasone dipropionate in asthma. Clin Allergy 1978;8:479-81.

35 Poukkula A, Alanko K, Kilpio K, et al. Comparison of a multidose powder inhaler containing beclomethasone dipropionate (BDP) with a BDP metered dose inhaler with spacer in the treatment of asthmatic patients. Clin Drug Invest 1998;16:101-10.

36 Toogood JH, White FA, Baskerville JC, et al. Comparison of the antiasthmatic, oropharyngeal and systemic glucocorticoid effects of budesonide administered through a pressurized aerosol plus spacer or the Turbuhaler dry powder inhaler. J Allergy Immunol 1997;99:186-93.

37 Jenkins $M$. Clinical evaluation of CFC-free metered dose inhalers. J Aerosol Med 1995:8:S41-7.

38 Agertoft L, Pedersen S. Influence of spacer device on drug delivery to young children with asthma. Arch Dis Child 1994;71:217-9.

39 Stradling JR, Pearson MG, Morice AH, et al. Efficacy and safety of a novel beclomethasone dipropionate dry powder inhaler (Clickhaler) for the treatment of adult asthma. Amsterdam Clinical Study Group. J Asthma 2000;37:183-90.

40 Crompton GK, Sanderson R, Dewar MH, et al. Comparison of Pulmicort pMDI plus Nebuhaler and Pulmicort Turbuhaler in asthmatic patients with dysphonia. Respir Med 2000;94:448-53.

41 Goldin JG, Tashkin DP, Kleerup EC, et al. Comparative effects of hydrofluoroalkane and chlorofluorocarbon beclomethasone dipropionate inhalation on small airways: assessment with functional helical thin-section computed tomography. J Allergy Clin Immunol 1999; 104:S258-67.

42 Juniper $\mathbf{E}$, Buist AS. Health-related quality of life in moderate asthma: $400 \mu \mathrm{g}$ hydrofluoroalkane beclomethasone dipropionate vs $800 \mu \mathrm{g}$ chlorofluorocarbon beclomethasone dipropionate. Chest 1999;11 16:1297-303

43 Ram FSF, Brocklebank DM, White J, et al. Pressurised metered dose inhalers versus all other hand-held inhaler devices to deliver beta-2 agonist bronchodilators for non-acute asthma (Cochrane Review). In: Cochrane Library. Issue 1. Oxford: Update Software, 2002.

44 Ramsdell JW, Klinger NM, Ekholm BP, et al. Safety of long-term treatment with HFA albuterol. Chest 1999:115:945-51.

45 Bronsky E, Ekholm BP, Kliner NM, et al. Switching patients with asthma from chlorofluorocarbon (CFC) albuterol to hydrofluoroalkane-134a (HFA) albuterol. J Asthma 1999;36:107-14

46 Bondesson E, Friberg K, Soliman S, et al. Safety and efficacy of a high cumulative dose of salbutamol inhaled via turbuhaler or via a pressurized metered-dose inhaler in patients with asthma. Respir Med 1998:92:325-30.

47 Ekstrom T, Andersson AC, Skedinger M, et al. Dose potency relationship of terbutaline inhaled via turbuhaler or via a pressurized metered dose inhaler. Ann Allergy Asthma Immunol 1995;74:328-32.

48 Johnsen CR, Weeke ER. Turbuhaler: a new device for dry powder terbutaline inhalation. Allergy 1988;43:393-5.

49 Hartley JPR, Nogrady SG, Seaton A. Long-term comparison of salbutamol powder with salbutamol aerosol in asthmatic out-patients. $\mathrm{Br} J$ Dis Chest 1979:73:271-6.

50 Kiviranta K. Fenoterol inhalation powder and aerosol in the treatment of asthma. Allergy 1985;40:305-7.

51 Boye K. A comparison of fenoterol powder capsules and fenoterol powder capsules and fenoterol metered dose spray in bronchial asthma. Eur J Respir Dis 1983;64:9-11

52 Ram FSF, Brocklebank DM, Muers $M$, et al. Pressurised metered-dose inhalers versus all other hand-held inhaler devices to deliver bronchodilators for chronic obstructive pulmonary disease (Cochrane Review). In: Cochrane Library. Issue 1. Oxford: Update Software, 2002

53 Blackhall MI. A dose response study of inhaled terbutaline administered via nebuhaler or nebuliser to asthmatic children. Eur J Respir Dis 1987;71:96-101.

54 Pierce RJ, McDonald CF, Landau LI, et al. Nebuhaler versus wet aerosol for domiciliary bronchodilator therapy (adults). Med J Aust 1992;156:771-4.

55 Grimwood K, Johnson-Barrett JJ, Taylor B. Salbutamol: tablets, inhalational powder or nebuliser? BM (Clin Res Ed) 1981;282:105-6.

56 Cissik JH, Bode FR, Smith JA. Double-blind crossover study of five bronchodilator medications and two delivery methods in stable asthma. Chest 1986:90:489-93.

57 Zainudin BMZ, Biddiscombe M, Tolfree SEJ, et al. Comparison of bronchodilator responses and deposition patterns of salbutamol inhaled from a pressurized metered dose inhaler, as a dry powder and as a nebulised solution. Thorax 1990;45:469-73.

58 Christensson P, Arborelius M, Lilja B. Salbutamol inhalation in chronic asthma bronchiole: dose aerosol vs jet nebulizer. Chest 1981;79:416-9.

59 Gervais A, Begin P. Bronchodilatation with a metered-dose inhaler plus an extension, using tidal breathing vs jet nebulisation. Chest 1987;92:822-4

60 Gomm S, Keaney N, Hunt L, et al. Dose-response comparison of ipratromium bromide from metered-dose inhaler and by jet nebulisation. Thorax 1983;38:297-301

61 Laursen L, Munch E, Weeke E, et al. Comparison of a $750 \mathrm{ml}$ spacer and a nebulizer in domiciliary treatment of severe chronic asthma with terbutaline. Eur J Respir Dis 1983;64:498-503.

62 Madsen E, Bundgaard A, Hidinger KG. Cumulative dose-response study comparing terbutaline pressurized aerosol administered via a pearshaped spacer and terbutaline in a nebulized solution. Eur J Clin Pharmacol 1982;23:27-30.

63 O'Reilly J, Buchanan D, Sudlow MF. Pressurized aerosol with conical spacer is an effective alternative to nebuliser in chronic stable asthma. BMU Clin Res Ed 1983;286:1548.

64 Prior JG, Nowell RV, Cochrane GM. High-dose inhaled terbutaline in the management of chronic severe asthma: comparison of wet nebulisation and tube-spacer delivery. Thorax 1982;37:300-3. 
65 Rochat T, Vonwil A, Bachofen $\mathrm{H}$. Die inhalation von beta-stimulatoren: Wirkungsvergleich zwischen sechs vershiedenen inhalationsgeraten. (Inhalation of beta-stimulantors: comparative effects of six different inhalation devices.) Schweiz Med Wochenschr 1983;113:314-9.

66 Shim C, Williams HM. Effect of bronchodilator therapy administered by canister versus jet nebulizer. J Allergy Clin Immunol 1984;73:387-90.

67 Stauder J, Hidinger K. Terbutaline aerosol from a metered dose inhaler with a $750-\mathrm{ml}$ spacer or as a nebulized solution. Respiration 1983:44:237-40.

68 Watanabe S, Turner WG, Renzetti AD Jr, et al. Bronchodilator effects of nebulized fenoterol. A comparison with isoproterenol. Chest 1981;80:292-9

69 Pedersen JZ, Bundgaard A. Comparative efficacy of different methods of nebulising terbutaline. Eur J Clin Pharmacol 1983;25:739-42.

70 Cushley MJ, Lewis RA, Tattersfield AE. Comparison of three techniques of inhalation on the airway response to terbutaline. Thorax 1983;38:908-13.

71 Salzman GA, Pyszczynski DR. A comparison of two delivery methods for aerosolized metaproterenol sulfate. J Asthma 1986;23:297-301.

72 Maldonado-Alanis ML, Ortega-Cisneros M, Linares-Zapien J, et al. Albuterol by nebulizer versus albuterol meter dose inhaler (MDI) with "Pulmona" spacer and MDI with "Ellipse" spacer. Ann Allergy Asthmo Immunol 1998;80:131

73 Cates CJ, Rowe BH. Holding chambers versus nebulisers for beta-agonist treatment of acute asthma (Cochrane Review). In: Cochrane Library. Issue 1, Oxford: Update Software, 2002.

74 Ikeda A, Nishimura K, Koyama H, et al. Comparison of the bronchodilator effects of salbutamol delivered via a metered-dose inhale with spacer, a dry powder inhaler, and a jet nebulizer in patients with chronic obstructive pulmonary disease. Respiration 1999;66:119-23.

75 Wetterlin K. Turbuhaler: a new powder inhaler for administration of drugs to the airways. Pharmacol Res 1998;5:506-8.
76 Berry RB Shinto RA, Wong FH, et al. Nebulizer vs spacer for broncodilator delivery in patients hospitalised for acute exacerbations of COPD. Chest 1989;96:1241-6.

77 Gross NJ, Petty TL, Friedman M, et al. Dose response to ipratropium as a nebulized solution in patients with chronic obstructive pulmonary disease. A three-centre study. Am Rev Respir Dis 1989;139:1188-91.

78 Hansen NCG. Terbutaline powder inhalation from Bricanyl Turbuhaler compared to terbutaline as nebulizer solution in severe chronic airways obstruction. Eur Respir J 1989:2:716-20.

79 Hansen NC, Evald T, Ibsen TB. Terbutaline inhalations by the Turbuhaler as replacement for domiciliary nebulizer therapy in severe chronic obstructive pulmonary disease. Respir Med 1994;88:267-71.

80 Hansen NC, Andersen PB. Salbutamol powder inhaled from the Diskhaler compared to salbutamol as nebulizer solution in severe chronic airways obstruction. Respir Med 1995;89:175-9.

81 Higgins RM, Cookson WOCM, Chadwick GA. Changes in blood gas levels after Nebuhaler and nebulizer administration of terbutaline in severe chronic airway obstruction. Bull Eur Physiopathol Respir 1987;23:261-4.

82 Jenkins SC, Heaton RW, Fulton TJ, et al. Comparison of domiciliary nebulized salbutamol and salbutamol from a metered-dose inhaler in stable chronic airflow limitation. Chest 1987;91:804-7.

83 Maguire GP, de Lorenzo LJ, Brown RB. Comparison of a hand-held nebulizer with a metered dose inhaler-spacer combination in acute obstructive pulmonary disease. Chest 1991;100:1300-5

84 Mestitz H, Copland JM, McDonald CF. Comparison of outpatient nebulized vs metered dose inhaler terbutaline in chronic airflow obstruction. Chest 1989;96:1237-40.

85 Turner JR, Corkery KJ, Eckman D, et al. Equivalence of continuous flow nebulizer and metered-dose inhaler with reservoir bag for treatment of acute airflow obstruction. Chest 1988;93:476-81. 